\title{
ANALISIS STATIONERITAS BETA DI BURSA EFEK JAKARTA
}

\author{
M. Fakhri Husein \\ Universitas Islam Negeri Sunan Kalijaga Yogyakarta
}

\begin{abstract}
This research tries to explore the issue of beta stationarity on Jakarta Stock Exchange. The tests indicate that the stationarity beta is dependent on the estimation interval. Investor will be better off using a longer estimation period. Understanding beta make it easier for investors to predict their future investments. By using 92 samples listed in BEJ, correlation analysis convey that beta tends not to stay in the same risk class from one period to the next.
\end{abstract}

Keywords: Stasionarity, Beta, correlation coefficient

\section{LATAR BELAKANG}

Pada model Capital Asset Pricing Model (CAPM) yang dikembangkan oleh Sharpe, Lintner, dan Mossin, tingkat return kembalian dalam keadaan ekuilibrium dari suatu sekuritas dihubungkan dengan risiko sistematiknya. Model ini tidak mengharuskan koefisien Beta dari suatu sekuritas stabil sepanjang waktu. Model ini hanya berasumsi bahwa partisipan pasar mengetahui koefisien Beta dari sekuritas tapi tidak memberikan petunjuk bagaimana cara memperoleh pengetahuan tentang Beta dari suatu sekuritas atau portofolio. Dalam penerapan model ini secara empirik, praktik yang biasa dilakukan adalah mengestimasi koefisien suatu sekuritas dengan cara meregresikan tingkat kembalian realisasi terhadap return realisasi dari portofolio pasar. Proses ini berasumsi bahwa koefisien Beta tersebut stationer.

Masalah stationeritas Beta pertama kali diuji oleh Blume (1971). Sejumlah penelitian berikutnya berkembang (lihat antara lain misalnya Almisher dan Kish 2000; Brooks, dkk 1998; Hodoshima, dkk 2000) untuk menyelidiki isu stasioneritas dari koefisien Beta. Studi setelah Blume menggunakan set data yang berbeda pada rentang waktu yang berbeda pula untuk mengamati perubahan Beta. Hasilnya secara umum menunjukkan bahwa Beta saham non stasioner, namun stasioneri meningkat ketika periode estimasi Beta meningkat.

Paper ini menguji stasioneritas dan mengamati keakuratan koefisien Beta untuk sampel perusahaanperusahaan yang listed di Bursa Efek Jakarta. Untuk pembandingan hasil maka digunakan dua jenis Beta yakni Beta Mentah yang belum dikoreksi dan Beta Koreksi. Koreksi Beta dilakukan karena tidak sinkronnya perdagangan saham untuk Bursa yang pasarnya tipis seperti di Bursa Efek Jakarta.

\section{DASAR TEORI DAN PENGEMBANGAN HIPOTESIS}

Beta merupakan suatu pengukur volatilitas (volatility) return suatu sekuritas atau return portofolio terhadap return pasar (Hartono, 2000). Beta merupakan pengukur risko sistematik dari suatu sekuritas atau portofolio relatif terhadap risiko pasar. Volatitilitas dapat didefinisikan sebagai fluktuasi dari return-return suatu sekuritas atau portofolio dalam suatu periode waktu tertentu. Jika fluktuasi return-return sekuritas atau portofolio secara statistik mengikuti fluktuasi dari return-return pasar, maka Beta dari sekuritas atau portofolio tersebut dikatakan bernilai 1. Karena fluktuasi juga sebagai pengukur dari risiko, maka Beta bernilai 1 menunjukkan bahwa risiko sistematik suatu sekuritas atau portofolio sama dengan risiko pasar. Beta sama dengan 1 juga menunjukkan jika return pasar bergerak naik (turun) sama besarnya mengikuti return pasar. Mengetahui Beta suatu sekuritas atau Beta suatu portofolio merupakan hal yang penting untuk menganalisis 
sekuritas atau portofolio tersebut. Beta dapat dihitung dengan teknik estimasi yang menggunakan data historis. Beta yang dihitung berdasarkan data historis ini selanjutnya dapat digunakan untuk mengestimasi Beta masa datang. Beta historis mampu menyediakan informasi tentang Beta masa depan. Beta historis ini dapat dihitung dengan menggunakan data historis berupa data pasar (return-return sekuritas dan return pasar), data akuntansi (laba-laba perusahan dan laba indeks pasar, atau data fundamental (menggunakan variabel-variabel fundamental).

Blume (1971) melakukan pengujian terhadap hubungan Beta dari waktu ke waktu. Blume menggunakan teknik regresi dengan data bulanan untuk menghitung Beta pasar. Data yang digunakan adalah data historis selama periode Juli 1954 sampai dengan Juni 1961 dan periode Juli 1961 sampai dengan 1968. la menghitung Beta untuk 8 macam portofolio untuk masing-masing periode. Portofolio yang dibentuk terdiri dari sebuah sekuritas, 2, 4, 7, 10, 20, 35 dan 50 buah sekuritas. Blume kemudian menghitung korelasi dari Beta masing-masing portofolio antara periode pertama dan kedua. Korelasi terendah hasil dari penelitian Blume adalah 0,60 dan korelasi tertingginya adalah 0,98. Ini menunjukkan bahwa Beta historis mempunyai hubungan dengan Beta masa datang. Hubungan ini akan semakin kuat untuk Beta portofolio yang mempunyai banyak sekuritas di dalamnya. Kesalahan pengukuran Beta portofolio akan semakin kecil dengan semakin banyaknya sekuritas di dalamnya karena kesalahan penghitungan Beta untuk masing-masing sekuritas akan saling meniadakan. Kesalahan pengukuran Beta portofolio yang semakin kecil akan mengakibatkan Beta portofolio semakin stabil dari suatu periode ke periode selanjutnya yang akibantya korelasi keduanya akan semakin besar. Ini juga berarti bahwa Beta portofolio dengan banyak aktiva merupakan prediktor yang lebih baik untuk Beta masa depan dibandingkan dengan Beta sekuritas atau portofolio dengan lebih sedikit sekuritas di dalamnya. Blume juga menyajikan bukti bahwa estimasi Beta cenderung mengarah ke nilai satu dari satu periode ke periode yang lain. Ini berarti bahwa nilai Beta yang kurang dari satu, akan naik mengarah ke nilai satu untuk periode berikutnya. Sebaliknya, estimasi Beta yang lebih besar dari satu, untuk periode selanjutnya akan cenderung mengarah ke nilai satu. Penelitian Blume menggunakan Beta suatu portofolio, dan tidak ke masing-masing sekuritas.

\section{1. Beta untuk Pasar Modal Berkembang}

Beta untuk pasar modal yang berkembang perlu disesuaikan. Alasannya adalah Beta yang belum disesuaikan masih merupakan Beta yang bias disebabkan oleh perdagangan yang tidak sinkron (Hartono, 2000). Perdagangan tidak sinkron ini terjadi di pasar yang transaksi perdagangannya jarang terjadi atau disebut dengan pasar yang tipis (thin market). Pasar yang tipis ini merupakan ciri dari pasar modal yang sedang berkembang. Beta sebagai pengukur volatilitas mengukur kovarian return suatu sekuritas dengan return pasar relatif terhadap risiko pasar. Kovarian dalam perhitungan Beta ini menunjukkan hubungan return suatu sekuritas dengan return pasar pada periode yang sama yaitu periode ke-t. Perhitungan Beta akan menjadi bias jika kedua periode tersebut tidak sinkron, yaitu periode ke-t dan periode return sekuritas bukan periodek ke-t, misalnya periode ke t-1 atau t-2 dan seterusnya. Periode ke-t dapat berupa harian, mingguan atau bulanan. Ketidaksamaan waktu antara return sekuritas dengan return pasar dalam perhitungan Beta disebabkan karena perdagangan sekuritas-sekuritas yang tidak sinkron. Perdagangan tidak sinkron terjadi karena beberapa sekuritas tidak mengalami perdagangan untuk beberapa waktu. Perdagangan tidak sinkron di pasar modal BEJ ditunjukkan oleh Hartono (2000). Untuk semua 257 emiten yang terdaftar di BEJ sampai dengan akhir tahun 1996, rata-ratajumlah hari perdagangan yang terjadi hanya sekitar148, 27 hari atau hanya sekitar 59,55\% saja dari 249 hari perdagangan yang ada selama setahun.

Untuk mengatasi bias Beta akibat tidak sinkronnya perdagangan sekuritas ini, maka beberapa metode dapat digunakan untuk mengoreksi Bias yang terjadi untuk Beta sekuritas akibat perdagangan tidak sinkron. Metode-metode ini diantaranya adalah yang diusulkan oleh Scholes dan Williams(1977), dan Dimson (1979). 
Scholes dan Williams memberikan solusi untuk mengoreksi bias dari perhitungan Beta akibat perdagangan tidak sinkron dengan rumus sebagai berikut (Hartono, 2000)

$$
\beta_{i}=\underline{\beta}-\underline{-1}+\beta_{i} \underline{0}+\underline{\beta}_{i}^{+1}
$$

dimana $\beta_{\mathrm{i}}$ adalah Beta sekuritas ke i yang sudah dikoreksi, $\beta_{\mathrm{i}}{ }^{-1}$ adalah Beta yang dihitung berdasarkan persamaan regresi untuk Ri periode ke-t dengan return pasar $(\mathrm{Rm})$ periode lag $\mathrm{t}-1, \quad \beta_{\mathrm{i}}^{0}$ adalah Beta yang dihitung berdasarkan persamaan regresi periode ke $t$ dengan $\mathrm{Rm}$ periode ke $\mathrm{t}, \beta_{i}^{+1} \quad$ adalah Beta yang dihitung berdasarkan persamaan regresi perode ke $t$ dengan $\mathrm{Rm}$ periode lead $t+1$, korelasi serial antara RM dengan $\mathrm{R}_{\mathrm{Mt}-1}$ yang dapat diperoleh dari persamaan regresi $\mathrm{Rmt}$.

Metode Dimson menyederhanakan cara Scholes dan Williams ini denagn cara menggunakan regresi berganda, sehingga hanya digunakan sebagai pengoperasian regresi saja berapapun banyaknya periode lag dan lead. Untuk n-buah periode lag dan lead, rumus Beta dikoreksi menurut metode Dimson untuk sekuritas ke i adalah:

$$
R i, t=\alpha i+\beta i^{-n} R_{M t-n}+\ldots .+\beta i R_{M t}+\ldots+\beta i^{+n} R_{M t+n}+\varepsilon_{i t}
$$

Dimana Ri,t adalah return sekuritas ke i periode ke $t, \mathrm{R}_{\mathrm{Mt}-\mathrm{n}}$ adalah return indeks pasar periode lag $\mathrm{t}-\mathrm{n}$, dan $\mathrm{R}_{\mathrm{Mt}+\mathrm{n}}$ adalah return indeks pasar periode lead $\mathrm{t}+\mathrm{n}$.

Metode Dimson memang merupakan metode yang sederhana karena hanya menggunakan sebuah pengoperasian regresi berganda saja dan Beta yang dikoreksi hanya dijumlahkan dari koefisien-koefisien ayng diperoleh dari regresi berganda tersebut. Fowler dan Rorke (dalam Hartono, 2000) berargumentasi bahwa metode Dimson yang hanya menjumlah koefisien-koefisien regresi berganda tanpa memberi bobot akan tetap memberikan Beta yang bias. Untuk satu periode lag dan lead, koreksi Beta dilakukan dengan tahapan sebagai berikut:

1. Operasikan persamaan regresi berganda seperti yang dilakukan di metode Dimson.

2. Operasikan persamaan regresi untuk mendapatkan koerlasi serial return indeks pasar dengan return indeks pasar periode sebelumnya sebagai berikut:

$$
\mathrm{R}_{\mathrm{Mt}}=\alpha_{\mathrm{i}}+\rho_{1 \mathrm{RMt}-1}+\varepsilon_{1}
$$

3. Hitung bobot yang digunakan sebesar

$$
\mathrm{Wi}=\frac{1+\rho_{1}}{1+2 . \rho_{1}}
$$

4. Hitung Beta dikoreksi sekuritas ke i yang merupakan penjumlahan koefisien berganda dengan bobot.

$$
\beta_{i}=w_{1}-\beta \mathrm{i}^{-1}+\beta_{\mathrm{i}}^{\mathrm{o}}+\mathrm{w}_{1} \cdot \beta 1^{+1}
$$

Cara lain untuk mengoreksi bias yang terjadi akibat perdagangan tidak sinkron yaitu dengan cara membuang observasi sampel yang menyebabkan terjadinya bias. Perdagangan tidak sinkron ini terjadi karena beberapa saham tidak aktif diperdagangkan. Dengan demikian, cara koreksi ini dilakukan dengan membuang observasi yang menunjukkan perdagangan tidak aktif.

Hartono dan Surianto (1999 dalam Hartono, 2000) menguji kebiasan Beta di Bursa Efek Jakarta. Data dari penelitian ini merupakan perusahaan-perusahaan yang terdaftar di BEJ mulai tanggal 22 Mei 995 sampai dengan 31 Mei 1997. Karena Beta banyak digunakan dalam penelitian event stufy, perhitungan Beta di penelitian mereka juga dihubungkan dengan suatu kejadian (event), yaitu kejadian pengumuman laba. Sampel yang berhasil dikumpulkan adalah sebanyak 74 perusahaan. Beta pasar merupakan rata-rata tertimbang dari Beta masing-masing sekuritas. Beta pasar yang belum dikoreksi yang dihitung dari rata-rata 74 perusahaan-tahun adalah 0,0676. Nilai Beta pasar ini secara statistik signifikan. Hal ini menunjukkan bahwa Beta sekuritas yang terdaftar di BEJ merupakan Beta yang bias. Beta masing-masing sekuritas kemudian dikoreksi dengan metode Scholes dan Williams, metode Dimson dan metode Fowler dan Rorke. Hasil dari koreksi menunjukkan bahwa metode yang paling tepat digunakan adalah metode Fowler dan Rorke dengan menggunakan empat lag dan empat lead koreksi. 
Penelitian ini berbeda dengan yang dilakukan oleh Hartono dan Surianto karena Beta koreksi dengan model Fowler dan Rorke digunakan untuk melihat kestabilan Beta.

\section{2. Stasioner vs Non-Stasioner}

Analisis stasioner berkaitan dengan data runtut waktu (time series). Tujuan analisis data runtut waktu adalah mempelajari struktur temporal (dinamik)dari data. Bila yang dianalisis hanya satu jenis data runtut waktu, misalnya data penjualan harian, maka disebut analisis runtut waktu univariat (univariate time-series). Analisis atas beberapa data selama periode yang sama dinamakan analisis runtut waktu multivariat/berganda (multivariate or multiple time-series). Analisis runtut waktu mendasarkan pada data runtut waktu yang stasioner. Arti stationer adalah apabila suatu data runtut waktu memiliki rata-rata dan memiliki kecenderungan bergerak menuju rata-rata. Untuk data yang stasioner, bila kita gambar data tersebut terhadap waktu maka akan sering melewati sumbu horizontal, dan autokorelasinya akan menurun dengan teratur untuk lag yang cukup besar. Sebaliknya bagi data yang tidak stasioner, varians menjadi semakin besar bila jumlah data runtut waktu diperluas, tidak sering melewati sumbu horizontal, dan autokorelasinya cenderung tidak menurun.

Penelitian ini menjadi menarik karena Scott (2000) mengajukan pertanyaan yang mempertanyakan keefektitan Beta (Is Beta Dead?). Ia menyatakan bahwa implikasi dari model CAPM adalah Beta suatu saham merupakan ukuran spesifik tunggal dari return ekspektasian atas saham. Jika CAPM mampu menangkap perilaku investor yang rasional, maka return saham seharusnya meningkat dan seharusnya tidak dipengaruhi oleh ukuran risiko spesifik perusahaan. Hal ini ditambah dengan temuan Fama dan French (Scott, 2000) yang menyatakan bahwa Beta memiliki kemampuan yang lemah dalam menjelaskan return saham. Malah, mereka menemukan bahwa daya penjelas yang lebih baik adalah rasio book to market. Penelitian lain yang dikutip oleh Scott yakni Schiller (1981) menunjukkan bahwa variabilitas indeks pasar saham besarnya beberapa kali dari variabilitas dividen secara agregat. Ackert dan Smith (1993) yang juga dikutip oleh Scott menyimpulkan bahwa jika informasi tambahan disediakan untuk menilai perusahaan, maka volatilitas dividen masa depan akan hilang.

Berawal dari inilah Scott berargumentasi bahwa CAPM jadi tidak jelas. Salah satu cara untuk menyelamatkan Beta seperti yang disarankan oleh Scott adalah mengakui bahwa Beta berubah sepanjang waktu. Untuk membuktikan hal ini, maka menarik jika diteliti dalam bentuk penelitian empiris. Hal ini untuk mengetahui apakah Beta konstan atau berubah sepanjang waktu.

Penelitian Kuhlman dan Weinraub (1994) menguji variabilitas jangka pendek untuk Beta portofolio kecil. la berargumen bahwa manajemen risiko portofolio sulit jika Beta tidak stasioner karena ketidakmampuan untuk memprediksi Beta masa depan. Hasilnya menunjukkan bahwa mungkin sekali mengurangi variabilitas Beta portofolio dengan menggabungkan secara sistematik menurut variabilitas Beta individual. Odabasi (2000) menguji kestasioneran koefisien Beta di Bursa Efek Istanbul. Uji yang dilakukan menunjukkan bahwa stasioneritas Beta tergantung pada interval estimasi. Investor akan lebih baik menggunakan periode estimasi yang lebih panjang.

Dari paparan diatas, maka hipotesis alternatif yang diajukan dalam penelitian ini adalah:

H1: Beta makin tidak stasioner jika periode pengamatannya diperluas

Periode pengamatan yang dilakukan dalam penelitian ini mengikuti interval waktu semesteran, tahunan, dua tahunan dan tiga tahunan seperti yang dilakukan oleh Odabasi (2000). Untuk analisis tambahan, maka Beta yang tidak dikoreksi dibandingkan pula dengan Beta koreksi. Pembandingan ini penting untuk mengantisipasi perdagangan saham yang tidak sinkron seperti yang disarankan oleh Hartono dan Surianto (1999). Disamping itu peneliti juga memilih sampel yang sahamnya diperdagangkan secara terus menerus sepanjang bulan selama 72 bulan pengamatan (6 tahun).

\section{METODA PENELITIAN}

\subsection{Pemilihan Sampel dan Sumber Data}

Dari 358 perusahaan yang listing di BEJ pada tahun 2001, maka terpilih sampel sejumlah 92 perusahaan yang memenuhi kriteria saham perusahaan sampel diperdagangkan secara terus menerus selama enam tahun pengamatan yakni 1992-1997. 
Dari 92 perusahaan tersebut maka karakteristik industri dari sampel dapat dilihat pada tabel 1.

Tabel 1

Karakteristik Sampel

\begin{tabular}{lc}
\hline Jenis Industri & Jumlah Sampel \\
\hline Aneka Industri & 17 \\
Industri Barang Konsumsi & 15 \\
Industri Dasar dan Kimia & 20 \\
Infrastruktur, Utilitas \& Transportasi & 3 \\
Keuangan & 18 \\
Perdagangan, Jasa \& Investasi & 14 \\
Pertambangan & 1 \\
Pertanian & 2 \\
Properti dan Real Estat & 2 \\
\hline
\end{tabular}

Beta saham setiap emiten diperoleh dari Indonesian Securities Market Database PPA Universitas Gadjah Mada. Beta saham harian yang ada dirata-ratakan untuk setiap bulan sehingga diperoleh rata-rata Beta bulanan untuk setiap emiten.

\subsection{Model Analisis}

Analisis Data dilakukan dengan statistik deskriptif untuk melihat karakteristik sampel dan Beta. Dari statistik deskriptif akan diketahui nilai rata-rata, deviasi standar, median, nilai terendah dan tertinggi setiap periode pengamatan. Untuk mengetahui stasioneritas Beta diperbandingkan korelasi dari berbagai periode pengamatan (Blume, 1971). Periode pengamatan yang dilakukan dalam penelitian ini adalah 6 bulan, tahunan, dua tahunan dan tiga tahunan.

\section{ANALISIS DAN HASIL PENELITIAN}

Tabel 2 memuat distribusi Beta mentah untuk 92 sampel perusahaan berdasarkan tahunan. Beta ini merupakan rata-rata Beta dalam satu bulan. Beta rata-rata untuk sampel bervariasi antara 0,381 (1994) dan. 0,542 (1992). Penjelasan yang mungkin untuk Beta yang kurang dari satu ini adalah karena kesalahan pengukuran, saham dikeluarkan dari sampel, dan bias kapitalisasi. Pada tabel 2 Beta yang negatif terdapat di seluruh tahun amatan dengan nilai terkecil sebesar -1,64 dan terbesar adalah 2,80.

Sedangkan untuk Beta koreksi (tabel 3), Beta rata-rata untuk sampel bervariasi antara 2,570 (1996) dan 2,783 (1992). Untuk Beta koreksi ini, nilai Beta yang terkecil adalah 0,750 (1993) dan terbesar 4,080 (1995).

Tabel 4 menghadirkan ringkasan distribusi Beta mentah untuk interval pengamatan yang berbedabeda yakni 6 bulan, 1 tahun, 2 tahun, dan 3 tahun. Dari tabel 4 tersebut dapat dilihat bahwa rata-rata Beta yang paling tinggi sebesar 0,598 terjadi pada periode estimasi 6 bulan. Sedangkan rata-rata Beta yang paling rendah sebesar 0,381 terjadi pada periode estimasi tahunan.

Tabel 5 menyajikan ringkasan distribusi Beta koreksi untuk interval pengamatan yang berbeda-beda yakni 6 bulan, 1 tahun, 2 tahun, dan 3 tahun. Rata-rata Beta yang paling tinggi terjadi pada periode pengamatan 6 bulan sebesar 2,787 dan rata-rata Beta paling rendah sebesar 2,525 juga terjadi pada periode pengamatan 6 bulan.

Dalam hal stabilitas Beta, yang dilihat dari deviasi standar yang makin kecil, dari data Beta mentah (tabel 4) tampak bahwa deviasinya agak meningkat seiring dengan periode estimasi yang lebih panjang $(0,543,0,546,0,549$ dan 0,553 masing-masing untuk periode amatan semesteran, tahunan, dua tahunan dan tiga tahunan). Dapat disimpulkan bahwa dengan menggunakan data mentah, maka Beta di Bursa Efek 
Jakarta cenderung tidak stabil walaupun penurunan kestabilan Betanya relatif kecil. Dilihat dari Beta koreksi (tabel 5) hasilnya juga konsisten yakni deviasinya meningkat seiring dengan periode estimasi yang lebih panjang $(0,326,0,328,0,331$ dan 0,335 masing-masing untuk periode amatan semesteran, tahunan, dua tahunan dan tiga tahunan). Penurunan kestabilan Betanya juga relatif kecil.

Stasioneritas Beta diuji dengan membandingkan estimasi Beta untuk seluruh periode amatan yang rentang waktu pengujian berbeda-beda ( 6 bulan, 1 tahun, 2 tahun dan 3 tahun). Untuk mengetahui stasioneritas Beta dilakukan dengan analisis perbandingan korelasi Beta antar berbagai periode pengamatan.

Rata-rata korelasi Beta mentah untuk periode amatan semesteran, tahunan, dua tahunan dan 3 tahunan (tabel 6) masing-masing adalah 0,72,0,46, 0,41 dan 0,32. Dari hasil ini tampak bahwa Beta cenderung tidak stasioner jika periode amatannya bertambah. Rata-rata korelasi Beta koreksi untuk periode amatan semesteran, tahunan, dua tahunan dan 3 tahunan (tabel 7) menunjukkan korelasi yang lebih kecil. Adapun korelasi Beta masing-masing adalah 0, 49, 0,08, 0,001 dan 0,09. Dengan kata lain setelah dihilangkan bias Betanya, justru Beta makin tidak stasioner dengan tingkat korelasi antar periode yang relatif sangat kecil (9\%-49\%).

Tabel 2

Distribusi Estimasi Beta Mentah Dalam Tahunan

\begin{tabular}{cccccc}
\hline Beta Mentah & $\begin{array}{c}\text { Rata-rata } \\
\text { Beta }\end{array}$ & Stddev & Median & Min & Max \\
\hline 1992 & 0.539 & 0.605 & 0.367 & -1.00 & 2.49 \\
1993 & 0.542 & 0.603 & 0.426 & -1.64 & 4.03 \\
1994 & 0.381 & 0.135 & 0.295 & -1.17 & 2.20 \\
1995 & 0.485 & 0.618 & 0.245 & -0.52 & 2.80 \\
1996 & 0.399 & 0.521 & 0.255 & -0.59 & 2.68 \\
1997 & 0.452 & 0.492 & 0.302 & -0.44 & 2.41 \\
Rata-rata 1992-1997 & $\mathbf{0 . 4 6 6}$ & $\mathbf{0 . 4 9 6}$ & $\mathbf{0 . 3 1 5}$ & $-\mathbf{0 . 8 9}$ & $\mathbf{2 . 7 7}$ \\
\hline
\end{tabular}

Tabel 3

Distribusi Estimasi Beta Koreksi Dalam Tahunan

\begin{tabular}{ccccccc}
\hline \hline TAHUN & $\begin{array}{c}\text { Rata-rata } \\
\text { Beta }\end{array}$ & Stddev & Median & Min & Max \\
\hline 1992 & 2.783 & 0.302 & 2.780 & 1.540 & 3.920 \\
1993 & 2.712 & 0.437 & 2.695 & 0.750 & 4.015 \\
1994 & 2.671 & 0.288 & 2.600 & 1.510 & 4.000 \\
1995 & 2.685 & 0.306 & 2.630 & 1.760 & 4.080 \\
1996 & 2.570 & 0.308 & 2.560 & 1.310 & 3.770 \\
1997 & 2.593 & 0.330 & 2.570 & 1.390 & 3.940 \\
Rata-rata 1992-1997 & 2.669 & $\mathbf{0 . 3 2 8}$ & $\mathbf{2 . 6 3 9}$ & $\mathbf{1 . 3 8}$ & 3.95 \\
\hline \hline
\end{tabular}


Tabel 4

Distribusi Estimasi Beta Mentah, Nilai Rata-Rata Untuk Berbagai Interval Estimasi

\begin{tabular}{|c|c|c|c|c|c|c|}
\hline \multicolumn{2}{|c|}{ PERIODE } & \multirow{2}{*}{$\begin{array}{c}\begin{array}{c}\text { Rata-rata } \\
\text { Beta }\end{array} \\
0.528\end{array}$} & \multirow{2}{*}{$\begin{array}{l}\text { Stddev } \\
0.590\end{array}$} & \multirow{2}{*}{\begin{tabular}{|c|} 
Median \\
0.337
\end{tabular}} & \multirow{2}{*}{$\begin{array}{c}\text { Min } \\
-0.870\end{array}$} & \multirow{2}{*}{$\begin{array}{l}\text { Max } \\
2.240\end{array}$} \\
\hline Semester & Satu 1992 & & & & & \\
\hline & Dua 1992 & 0.549 & 0.620 & 0.397 & -1.000 & 2.490 \\
\hline & Satu 1993 & 0.598 & 0.610 & 0.473 & -1.640 & 3.520 \\
\hline & Dua 1993 & 0.486 & 0.590 & 0.376 & -1.290 & 4.030 \\
\hline & Satu 1994 & 0.345 & 0.376 & 0.288 & -1.170 & 1.320 \\
\hline & Dua 1994 & 0.417 & 0.485 & 0.303 & -0.750 & 2.200 \\
\hline & Satu 1995 & 0.469 & 0.596 & 0.245 & -0.520 & 2.550 \\
\hline & Dua 1995 & 0.501 & 0.639 & 0.245 & -0.510 & 2.800 \\
\hline & Satu 1996 & 0.427 & 0.568 & 0.260 & -0.590 & 2.680 \\
\hline & Dua 1996 & 0.371 & 0.467 & 0.251 & -0.560 & 1.600 \\
\hline & Satu 1997 & 0.386 & 0.443 & 0.270 & -0.440 & 1.950 \\
\hline & Dua 1997 & 0.518 & & 0.339 & -0.270 & 2.410 \\
\hline & RATA-RATA & 0.466 & 0.543 & 0.315 & -0.801 & 2.483 \\
\hline \multirow[t]{7}{*}{ Tahunan } & 1992 & 0.539 & 0.605 & 0.367 & -1.000 & 2.490 \\
\hline & 1993 & & 0.603 & 0.426 & -1.640 & 4.030 \\
\hline & 1994 & 0.381 & 0.435 & 0.295 & -1.170 & 2.200 \\
\hline & 1995 & 0.485 & 0.618 & 0.245 & -0.520 & 2.800 \\
\hline & 199 & 0.399 & 0.521 & 0.255 & -0.590 & 2.680 \\
\hline & & 0.452 & 0.492 & 0.302 & -0.440 & 2.410 \\
\hline & & 0.466 & 0.546 & 0.315 & -0.893 & 2.768 \\
\hline \multirow[t]{4}{*}{ Dua Tahunan } & 92-1993 & 0.540 & 0.604 & 0.404 & -1.640 & 4.030 \\
\hline & 1994-1995 & 0.433 & 0.537 & 0.276 & -1.170 & 2.800 \\
\hline & 1996-1997 & 0.426 & 0.507 & 0.278 & -0.590 & 2.680 \\
\hline & RATA-RATA & 0.466 & 0.549 & 0.319 & -1.125 & 3.17 \\
\hline \multirow[t]{3}{*}{3 Tahunan } & 1992-1994 & 0.487 & 0.558 & 0.348 & -1.640 & 4.030 \\
\hline & 1995-1997 & 0.445 & 0.547 & 0.270 & -0.590 & 2.800 \\
\hline & RATA-RATA & 0.466 & 0.553 & 0.309 & -1.115 & 3.415 \\
\hline
\end{tabular}


Tabel 5: Distribusi Estimasi Beta Koreksi, Nilai Rata-Rata Untuk Berbagai Interval Estimasi

\begin{tabular}{lcccccc}
\hline \multicolumn{1}{c}{ PERIODE } & $\begin{array}{c}\text { Rata-rata } \\
\text { Beta }\end{array}$ & Stddev & Median & Min & Max \\
\cline { 1 - 3 } & 2.669 & 0.326 & 2.643 & 1.463 & 3.880 \\
SEMESTER & 2.669 & 0.328 & 2.639 & 1.377 & 3.954 \\
TAHUNAN & 2.669 & 0.331 & 2.640 & 1.190 & 4.057 \\
DUA TAHUNAN & 2.669 & 0.335 & 2.640 & 1.030 & 4.115 \\
\hline
\end{tabular}

Tabel 6:

Koefisien Korelasi Beta Mentah Untuk Berbagai Perbandingan Periode

\begin{tabular}{lc}
\hline \hline Jenis Periode & $\begin{array}{c}\text { Korelasi Beta } \\
\text { Berdasarkan Beta Bulanan }\end{array}$ \\
\hline Semesteran & 0.72 \\
Tahunan & 0.46 \\
Dua Tahunan & 0.41 \\
Tiga Tahunan & 0.32 \\
\hline \multicolumn{2}{c}{ Koefisien Korelasi Beta Koreksi } \\
\multicolumn{1}{c}{ Untuk Berbagai Perbandingan Periode } \\
\multicolumn{2}{c}{ Korelasi Beta } \\
\hline \hline Jenis Periode & Berdasarkan Beta Bulanan \\
Semesteran & 0.49 \\
Tahunan & 0.07 \\
Dua Tahunan & 0,00 \\
Tiga Tahunan & 0,09 \\
\hline
\end{tabular}


Tabel 8.

Korelasi Beta Koreksi Berdasarkan Beta Bulanan

\begin{tabular}{|c|c|c|}
\hline Jenis Periode & Periode Estimasi & $\begin{array}{c}\text { Korelasi Beta } \\
\text { Berdasarkan Beta Bulanan }\end{array}$ \\
\hline \multirow[t]{12}{*}{ Semesteran } & Paruh Pertama 1992 - Paruh Kedua 1992 & 0.60 \\
\hline & Paruh Kedua 1992 - Paruh Pertama 1993 & 0.34 \\
\hline & Paruh Pertama 1993 - Paruh Kedua 1993 & 0.50 \\
\hline & Paruh Kedua 1993 - Paruh Pertama 1994 & 0.25 \\
\hline & Paruh Pertama 1994 - Paruh Kedua 1994 & 0.70 \\
\hline & Paruh Kedua 1994 - Paruh Pertama 1995 & 0.43 \\
\hline & Paruh Pertama 1995 - Paruh Kedua 1995 & 0.74 \\
\hline & Paruh Kedua 1995 - Paruh Pertama 1996 & 0.38 \\
\hline & Paruh Pertama 1996 - Paruh Kedua 1996 & 0.59 \\
\hline & Paruh Kedua 1996 - Paruh Pertama 1997 & 0.59 \\
\hline & Paruh Pertama 1997 - Paruh Kedua 1997 & 0.29 \\
\hline & RATA-RATA & 0.49 \\
\hline \multirow[t]{6}{*}{ Tahunan } & $1992-1993$ & 0.048 \\
\hline & $1993-1994$ & 0.055 \\
\hline & $1994-1995$ & 0.114 \\
\hline & $1995-1996$ & 0.175 \\
\hline & $1996-1997$ & -0.008 \\
\hline & RATA-RATA & 0.077 \\
\hline \multirow[t]{3}{*}{ Dua Tahunan } & 1992/1993-1994/1995 & 0.041 \\
\hline & 1994/1995-1996/1997 & -0.040 \\
\hline & RATA-RATA & 0.001 \\
\hline \multirow[t]{2}{*}{3 Tahunan } & 1992/93/94 - 1995/96/97 & 0.090 \\
\hline & RATA-RATA & 0.090 \\
\hline
\end{tabular}

\section{SIMPULAN DAN KETERBATASAN PENELITIAN}

\subsection{Simpulan}

Penelitian ini lepas dari kemungkinan kelemahan metodologinya, maka hasilnya menunjukkan bahwa Beta mentah rata-rata untuk sampel bervariasi antara 0,381 (1994) dan. 0,542 (1992). Sedangkan untuk Beta koreksi, Beta rata-rata untuk sampel bervariasi antara 2,570 (1996) dan 2,783 (1992).

Dilihat dari interval pengamatan yang berbeda-beda dari Beta mentah yakni 6 bulan, 1 tahun, 2 tahun, dan 3 tahun, maka rata-rata Beta yang paling tinggi sebesar 0,598 terjadi pada periode estimasi 6 bulan dan paling rendah sebesar 0,381 terjadi pada periode estimasi tahunan.

Untuk Beta koreksi untuk interval pengamatan yang berbeda-beda yakni 6 bulan, 1 tahun, 2 tahun, dan 3 tahun, rata-rata Beta yang paling tinggi terjadi pada periode pengamatan 6 bulan sebesar 2,787 dan rata-rata Beta paling rendah sebesar 2,525 juga terjadi pada periode pengamatan 6 bulan.

Dalam hal stabilitas Beta, yang dilihat dari deviasi standar yang makin kecil, dari data Beta mentah tampak bahwa deviasinya agak meningkat seiring dengan periode estimasi yang lebih panjang Dapat disimpulkan bahwa dengan menggunakan data Beta mentah, maka Beta di Bursa Efek Jakarta cenderung tidak stabil walaupun penurunan kestabilan Betanya relatif kecil. Dilihat dari Beta koreksi hasilnya juga 
konsisten yakni deviasinya meningkat seiring dengan periode estimasi yang lebih panjang Tampak bahwa deviasi standar dari dua jenis Beta ini menunjukkan kecenderungan yang sama. Penurunan kestabilan Betanya juga relatif kecil.

Stasioneritas Beta yang diuji dengan membandingkan korelasi estimasi Beta untuk seluruh periode amatan yang rentang waktu pengujian berbeda-beda ( 6 bulan, 1 tahun, 2 tahun dan 3 tahun) Rata-rata korelasi Beta mentah untuk periode amatan semesteran, tahunan, dua tahunan dan 3 tahunan Beta cenderung tidak stasioner jika periode amatannya bertambah. Rata-rata korelasi Beta koreksi untuk periode amatan semesteran, tahunan, dua tahunan dan 3 tahunan (tabel 7) menunjukkan korelasi yang lebih kecil. Seharusnya jika bias Betanya dihilangkan seharusnya korelasi Betanya lebih baik. Hal ini tidak terjadi pada penelitian ini.

\subsection{Keterbatasan dan Implikasi Penelitian}

Penelitian ini hanya membahas stasioneritas Beta saham individual sehingga penelitian berikutnya dapat membahas stasioneritas Beta dari sisi portofolio saham. Disamping itu, penelitian ini hanya memasukkan dua jenis beta yakni Beta Mentah dan Beta Koreksi dengan model Fowler dan Rorke saja. Penelitian berikutnya lebih baik lagi memasukkan beberapa model Beta sehingga stasioneritas Beta akan diketahui secara komprehensif.

\section{DAFTAR PUSTAKA}

Almisher, M.A. Dan R.J. Kish., (2000), "Accounting Betas-An Ex Anti Proxy For Risk Within The IPO Market", Journal of Financial and Strategic Decisions, Vol. 13, No. 3, Hal. 23-35

Baesel, J.B., (1974), "On the Assessment of Risk: Some Further Considerations", Journal of Finance, 29, 1941-4

Blume, M.E., (1967), "On The Assessment of Risk", The Journal of Finance. Vol. XXVI No. 1

Brooks, (1998), "An Investigation Into The Extent Of Beta Instability In The Singapore Stock Market", PacificBasin Finance Journal, Vol. 6, Hal. 87-101

Foster, G., Olsen, C., Shevlin, T., (1984), "Earnings Release, Anomalies And The Behavior Of Security Returns", The Accounting Review 59, 574-603

Gonedes, N. Dopuch, N., (1974), "Capital Market Equilibrium, Information Production, And Selecting Accounting Techniques: Theoretical Framework And Review Of Empirical Work", Journal of Accounting Research Supplement 12, 48-130

Hartono M., J., (2000), Teori Portofolio dan Analisis Investasi. Edisi Kedua. BPFE, Jogjakarta

Hodoshima, (2000), "Cross-Sectional Regression Analysis Of Return And Beta In Japan", Journal Of Economics And Business, Vol. 52, Hal.515-533

Kuhlman, B.R, Weinraub, H.J., (1994), "Reducing the Short Term Variability of Small Portfolio Betas", Journal of Financial and Strategic Decisions. Vol 7 No 3

Lin. W.T., Chen, Y.H., and Boot, J., (1992), "The Dynamic and Stochastic Instability of Betas: Implications for Forecasting Stock Returns", Journal of Forecasting, 11. 517-541 
Liu, J. Thomas, J., (2000), "Stock Returns And Accounting Earnings", Journal Of Accounting Research 38, 71101

Mikhail, M., Walther, B., Willis, R., (1999), "Does Forecast Accuracy Matter To Security Analysts?" The Accounting Review 74, 185-200

Odabasi, A., (2000), "Evidence on the Stationarity of Beta Coefficients: The Case of Turkey", http://www.iseiorg/about/majordev.htm

Roenfeldt, R., (1978), "Further Evidence on the Stationarity of Beta Coefficients", Journal of Financial and Quantitative Analysis, March, 11-21

Roll, R. (1983), "On Computing Mean Returns And The Small Firm Premium", Journal Of Financial Economics 12, 371-386

Scholes, M., Williams, J. (1977), "Estimating Betas From Nonsynchroneous Data", Journal Of Financial Economics 5, 309-327

Scott, W.R., (2000), Financial Accounting Theory. Second Edition. Prentice Hall, Ontario 